\title{
Marketing Communication as an Element of Public Communication at Schools
}

\author{
By Joanna Kolodziejczyk*
}

This article deals with the problem of public communication at schools. Modern society expects that any public body will share reliable information concerning its operation. This is also the case with schools. Different stakeholders interested in school functioning will seek information, that is important from their point of view (school staff, students, students' parents, school graduates, authorities in charge and supervising, organizations working with the school and wider local communities). These different groups will not only seek information, but will also be interested in meeting public communication standards. Instruments used in marketing communication are supposed to support schools in achieving their main objectives, though often they serve market purposes - that is, attracting new students. The aim of the research was to obtain information on how schools perceive and perform their role as a participant in the process of public communication. It tried to determine what content dominates in the communication with local communities, what means of public communication are used by schools and what functions are performed by public messages generated by schools.

Keywords: Marketing communication, Public communication, Poland, School

\section{Introduction}

Public schools in Poland are obliged to provide information about their functioning. These obligations arise from the law, according to which they have to provide public information in the Public Information Bulletin, as is the case with other public organizations as well (The Regulation 2007). The range of information and the list of organizations that are obliged to provide it are regulated by law. By public information we understand any piece of information on public affairs, subject to publication and reuse by the rules and procedures established in the Act on Access to Public Information (The Act 2001). Apart from publishing information in the Public Information Bulletin, schools are obliged to promote the value of education, as stated in the Regulation on Pedagogical Supervision (The Regulation 2013). The appendix to the Regulation formulates the requirements for schools and among them the requirement to promote the value of education. The description of the requirement states, among others, that the actions undertaken by the school or educational institution promote the value of education in the local community.

Apart from the legal aspect, the fundamental purposes of schools' functions, namely teaching, learning and education, are the important factor in the context of communication between school and stakeholders. To fulfill these purposes, the school cooperates simultaneously with different subjects in the external

*Lecturer, Jagiellonian University in Krakow, Poland. 
environment, building a space of communication that allows the gathering and releasing of information. While caring for students' development, the school is expected to be able to respond to the needs of various stakeholders, whose actions affect that development. By that I mean mostly parents, whose involvement, as has been shown in many research studies, influences the educational achievements of students (e.g. Borgonovi and Mont 2012, Hill and Tyson 2009) and skillful communication is an important field of cooperation between the school and parents (Epstein 2001).

Managing the communication both inside and outside the organization is one of the fundamentals of school management. Many practitioners and researchers dealing with these issues believe that marketing communication is a significant element of management (Davis and Ellison 1997, Fazlagić 2003, Hall 2007, Lockhart 2005, Pardey 1991). The instruments of marketing communication used at school are mainly supposed to serve the purposes of building a positive image of the school in the local environment, and for the purposes of recruitment.

The article raises the issue of communication between schools and stakeholders. I would like to discuss two questions: first, how we should understand the public communication performed by school, and second, how, in this context, we should interpret marketing communication with its aims and its dominant persuasive function.

\section{Public Communication - Characteristics, Values, Problems}

Public communication is defined as formal communication that occurs in a given communication (information) space, and is aimed at conveying and exchanging information of public interest and sustaining social connections. It is performed by public institutions responsible for that process (Dobek-Ostrowska 2011: 122). This perception of communication goes beyond mere informing, which is a one-way process, and assumes the interactive role of communicating, its two-way character, for it its inclusive function that is important here. Public communication will then be a broader activity than "providing information" that is regulated by law. Public organizations are made responsible for public communication since they manage that process.

Public communication is seen as one of the systems of social communication, next to organizational, political and mass communication (Dobek-Ostrowska 1999). Examining the relations between public communication and the communication systems listed above, we notice that the term "public communication" is semantically close to the notions of "political communication" and "mass communication". In the context of this article, I would like to highlight certain aspects of these similarities. The semantic fields of these notions overlap, particularly when it comes to the so-called public discourse, which involves various subjects in the public media or to the debates on issues that are important for the citizens, initiated and conducted by public institutions. On the one hand, a media debate meets the criteria of public communication as it concerns socially significant problems and involves the citizens, but on the other hand, it can be a 
part of political communication. The audience will easily associate these two notions, particularly when politicians participate in the debate. The question of defining whether the communication is public or political, occurs when those who participate in the debate and send the message are politicians performing major public functions, such as the prime minister, the president, the ministers or local authorities, who are identified by the audience as representatives of political parties. Both public debates and politicians' speeches fit into the system of mass communication as they use mass media such as television or the Internet. School, as a public organization, should not take part in the process of political communication, just like any other institution of public service (Dobek-Ostrowska 2011: 124), even though it often is an object of political dispute.

The semantic fields of these terms overlap as well when we take a closer look at the functions of public communication included in the aforementioned definition, among which are: informing the public, making information public, raising public values, listening to the feedback and questions from the citizens, watching the public debate, contributing to the extension of social connections or accompanying social changes (Dobek-Ostrowska 1999: 135, Zémor 1995: 5). These functions, typical of public communication, may as well be attributed to political or mass communication.

The vagueness of these terms is apparent and makes it problematic to differentiate between them precisely. The intention of communication, subordinate to the aim that is serving the citizens, seems to be one of the differences. In other words, public communication should not be conditioned by the interest of the sender but of the receivers, such as an applicant in an office, a parent at school or a patient in a public hospital. In accordance with the idea of public service institutions, which public organizations are supposed to be, the "good" of the citizen is the necessary condition. Further implications would then concern the qualities and values that should be essential for public communication from the citizen's perspective. Among them, we could list mutual trust in the participants of the process of communication, transparency of communication, inclusiveness - including the citizens in the dialogue, symmetry in communication, understood as the partnership between the sender and the receiver, agreement between the participants of communication, intelligibility of the messages, correctness of the content, objectivity in providing the information and where it is its trustworthy and accurate.

Public communication defined this way will fulfill the postulates of deliberative and participatory democracy, which includes the citizens in public affairs, and will shift the emphasis from the passive participation of the citizen as a listener in public communication to an active attitude of a participant who reacts to the public message, formulates his opinions, and comes up with postulates. Following Habermas (1999), understanding public communication in this way, we can stress the necessity of aiming at an "ideal speech situation" that assumes inclusiveness, liberty in expressing one's opinions, equal rights of the partners and their ethical attitude shown in their truthfulness (Habermas 2004: 38). In this view of public communication can be found some postulates of the communitarians, such as the involvement of the citizens in public affairs along with a high level of 
responsivity, the idea of communality and the opposition to excessive individualism (Kowalczyk 2009: 97-102, Śpiewak 2004).

Satisfying these "quality" requirements of public communication might be a problem. The representatives of public organizations take part in the communication process as actors, who by law are responsible for the released messages and always have to refer to the law in force. Therefore, it can be a problem for them to publically criticize or deny legal acts. This factor can be a barrier in an open dialogue and in approaching the conception of communicative action by Habermas (1999), which emphasizes, among others, the liberty in expressing one's opinions. The stakeholders, as participants of the communication process, might fail to rise to the challenge of openness as well, for instance when they do not have the sense of security and the certainty that their opinions will not provoke a critical attitude of the representatives of a given institution towards them. These aspects among others, connected to power and the communication strategies that result from it, make the theory of communicative action by Habermas (1999) an object of criticism, for instance Pierre Bourdieu who views it as utopian. According to Bourdieu, it does not take into consideration the inequality of the economic and cultural capital (inequality of knowledge, information, opinions and socially conditioned opportunities), the invented theory does not refer to practice. In real conditions of communication, as stated by Bourdieu, there always appear particular interests, dominance and discrimination, shown in the limited access to higher positions and the limited possibility and capability of speaking out and shaping the public opinion (Żardecka-Nowak 2008).

\section{Public Communication in Schools}

The signalized problems concerning public communication of public organizations affect schools as well. The stakeholders might expect detailed information on their functioning. Various groups (school employees, students, their parents, graduates, local educational authorities, supervising institutions, organizations cooperating with the school or the broadly understood local community, prospective students and parents included) might seek different information but they will all be interested in receiving a message that meets the criteria of public communication, in other words, a message that is, among others, trustworthy, accurate and clear. Public communication might occur on different levels of communication. It can be performed both directly and indirectly through the media and it can take the form of oral or written communication. The goals and functions of communication performed by the school might be vary, as well as its content depending on the context. The message might then have an informative, educational or inclusive function and help build mutual understanding between the sender and the receiver. The messages should promote the value of education in the local community.

In a communicative action, as understood by Habermas (1999), the sender does not use the means typical for persuasive communication in order to pursue 
his interests because, in that perspective, communication does not have a strategic character - it is not meant to be a means of pursuing particular interests of individuals or groups. Communication serves the purpose of reaching consensus and its ultimate goal is the pursuit of social interest, acting for the public good. It should also be an ethical activity. Schools, just like any other public organizations, as I have already mentioned, are expected to perform communicative activities that would fulfill the informative function but which would also facilitate the democratic process of including the stakeholders in the process of social communication, social debate, raising questions, postulates, formulating opinions etc. These postulates are reflected in the educational law, for instance in the requirements for schools such as the one concerning the partnership of school and parents. The description of this requirement states that the school or institution gathers and uses the feedback from parents on its work, and parents participate in the decision-making concerning school affairs and in the undertaken actions (The Regulation 2013). Public communication in schools is supposed to contribute to the expansion of social connections, to bond the local community and to involve it in active co-management of the organizational changes or in consulting new solutions.

\section{The Aim and Object of the Research, Methods and Research Tool}

Since 2009, internal and external evaluations have been carried out in all educational institutions in order to make public the information about their functioning in various areas. The requirements for school established by the state are the object of the external evaluations (The Regulation 2013). The evaluation provides information about the actions undertaken by the school in the examined areas and about the level of the fulfillment of state requirements. Schools receive a report containing the results and conclusions of the external evaluation and the information about the fulfillment of the requirements. The reports are made public and are available on the Internet.

All data from the evaluations is archived. Thanks to that, quantity and quality analyses can be carried out. These analyses provide information on the functioning of the school in a given area; the conclusions might be used to create educational policies on a regional or national level. In the research that was carried out, the existing data was used.

The purpose of the research was to gather information on how schools perceive and fulfill their role as a participant in the process of public communication. I was trying to find the answers to the questions: what methods of public communication are used by schools, and what content is prevalent in the communication with the local community. The method of analyzing the existing data was used. In the research, I used the results of external evaluations conducted in Poland in 2013 (from 1.01.2013 to 30.06.2013). 527 external evaluations were conducted in that period in primary schools. The chosen $105(20 \%)$ statements by primary school headmasters, gathered through an on-line survey, were analyzed. 
Primary schools situated in towns of different size had been chosen for the analysis.

The research material was diverse, in terms of the length of the statements by given respondents; they gave from two up to a couple of dozen examples. This particular research material was chosen because the survey had been filled out by schools' headmasters, that is by those who manage the process of communicating with stakeholders. Their responses could be affected by the fact that the headmasters were participating in the external evaluation.

I treated the research material as existing data and carried out a quality analysis of its content. In the first stage of the analysis, I searched for the answer to the question how school communicates with stakeholders. I analyzed each statement separately and I created codes, taking into consideration the entire research material. In the second step of the analysis, I looked at the content of the messages released by schools and encoded the entire research material. The next stage of the analysis was to re-examine the entire material in terms of the created code categories, discarding some of the codes and creating broader code categories. This list, with examples of the analyzed material, is presented further in the article.

The question answered by the headmasters was: "What information on the offer, regarding the activities or the attainments of students, has recently been made public in the local environment? Give examples".

\section{The Methods of Public Communication Used by Schools and its Content - The Results of the Research}

In the analysis of the existing data that was carried out, we were trying to find out about the methods of public communication and the content of the released messages. In the analysis, the respondents' answers were categorized in the two areas listed below and some examples given by the headmasters were quoted. The results of the data analysis are presented below.

\section{The Methods of Public Communication used by Schools}

In the course of the analysis, two methods used by schools to communicate with the stakeholders were identified: direct and indirect.

\section{Indirect communication:}

- local media (press, radio, television): "we put information about the school life and about our students' attainments in the regional TV and in a local paper ", "in the past two years local media have released around 200 pieces of information on our school", "regular articles and interviews with the headmaster in the community's municipal newsletter";

- websites: "we put information about the school life on the website", "current events from the school life - photos, album, school chronicle published on the school website"; "the information appeared on the school website", 
- publicity: "the publication of an occasional folder presenting the activities and attainments of our students", "the information on the school offer, activities and attainments given to the parents from the nearby nursery schools in a form of a folder", "information leaflets about the school";

- advertising banners and posters: "posters on the school's front door";

- church announcements: "the information about the school offer is released in the Bernardines Basilica", "the results are announced by the priest";

- notice board at school;

- school newsletter.

Direct communication:

- school open day;

- directly during the meetings: "First Grade Academy - the school presents its educational offer in the environment, familiarizes the parents of preschool children with the school activity";

- at the Municipal Council sessions;

- during school ceremonies: "Parents Day combined with a talent show the school presents the students' and school's attainments among other things", "During the commemoration of the 25 years of our school we showed a multimedia presentation about the school's achievements and current activities performed in our school and a short publicity clip presenting the school's educational offer";

- parent-teacher conferences: "informing the parents during the conferences", "information is given during the parent-teacher conferences".

The Content of the Messages sent to Local Public

In the course of the analysis, a few categories connected to the content of public messages were identified:

- information about the ceremonies and events that are being held or are to be held at school: school plays, jubilees, oath days, festivals and other celebrations: "in December 2012, the school released information about the nativity play that was planned", "first grade Oath Day", "information about the inclusive St. Nicholas Day organized by our school for the students from a Special Education Centre", "Christmas meeting for lonely people", "family festival Baked Potato and Autumn Gifts Day", "organizing St. Andrew's Day party", "Pope's Day, Independence Day, National Education Day", "the first grade swearing-in ceremony", "the commemoration of 40 years of the school name";

- information about social and charity events organized by the school: "information about a charity event - raising gifts for the Mother and Child Home 'Nazaret' in Otwock", "raising food for Christmas as part of the national action of Food Banks", "social action 'Góra Grosza'", "charity action 'Help for Damian'", in the last few months, the school has taken part in actions presented in the local media: 1 . Street happening "Words hurt 
for the rest of your life" - participation in a national social campaign against verbal violence towards children, 2. Participation in the Campaign of Suwałki White Ribbon - 'Step out of the violence shadow', "information about helping to organize an operation for an ill dog from a shelter";

- information about students" achievements: "we inform about the achievements in knowledge and sport competitions","information about the best students", "students" achievements in competitions and contests', "students' achievements in contests";

- students' attainments: "test results", "the results obtained by the students in the external sixth grade test", "making public the results of the external tests at the teacher-parent conferences and at the Municipal Council sessions";

- information about projects: "information about the Polish-Lithuanian Exchange programme in which the school participates as a part of the Comenius project", "realizing the project School of Equal Opportunities";

- information about student trips and educational camps: "student trip", "a trip to Rome to fetch St. Joseph Calasanctius's relics", "a trip to Christmas baubles manufactory", "skiing and snowboard camp, educational camp and other curricular trips";

- information about the offer: "extra-curricular classes", "special interests groups", "information about extra-curricular and specialist classes organized by the school", "extended curriculum in Polish, Mathematics, Art and Languages", "second foreign language classes from the fourth grade", "good and safe school location";

- information about the obtained certificates: "obtaining the certificate of the Innovative School", "in July, the school was granted a 1-class certificate of the school promoting scientific motion";

- thanks: "thanks from the head of the Municipal Social Welfare Centre for the initiative and cooperation", "thanks to the sponsors", "thanks to the parents for supporting the action 'We make dreams come true'";

- information about teacher's success: "our teacher's success"

- information about meeting with interesting people;

- information on the development of school premises, educational aids and renovations: "opening of a sports field complex", "school renovations", "information on school thermomodernization", "opening of a new sports hall";

- volunteering: "volunteers (our school graduates) helping students from the 1-3 grades with studying and doing their homework"

- information on awards: "rewarding the best employees", "winning two main awards in a contest 'Water - Earth's Treasure' organized by the Municipal Water and Sewerage Department in Lublin", "the best students awarded with books";

- information concerning communication and cooperation with parents and the attempts to involve them: "our students' parents, with help from the Polish teacher, staged a play 'Cinderella' in the Municipal Culture Centre", "parents together with their children participate in the regular 
meetings of the school drama club", "informing parents on the changes in the organization of the sixth grade test", "parent-teacher conferences";

- Information on school work organization: "school timetable, extracurricular classes timetable", "the schedule of extra-curricular classes organized by the school";

\section{The Functions of Communication and Messages Released by Schools - Conclusions from the Research}

The results of the quality analysis show that schools use the majority of the contemporary, standard means of public communication, both in indirect and direct communication. Thanks to the aforementioned means of communication, schools can potentially get across to various receivers. However, the analyzed statements by the headmasters show that, apart from websites, schools do not use other means of communication via the Internet, such as blogs or interactive social media which can hinder getting across to all interested audiences. When the headmasters list direct means of communication, such as parent-teacher conferences, the way they describe the communication process indicates that it is one-way communication. They state for example, that 'attainments are presented', "parents are informed", "information was given", "parents are familiarized with school activit", "a multimedia presentation was shown". Only occasionally, are some statements made by the headmasters which indicate that they had planned consciously an interactive, two-way process of communication.

The content of the analyzed documents is diverse. More than ten categories have been identified showing the picture of primary school public communication. By pointing at these areas, the headmasters apparently see them as important in the communication with the environment. If we take a closer look at what is, according to the headmasters, the core content of the messages, we see that they choose the content not only for informational purposes but also for its persuasive function. Only a few of the categories have a potentially neutral character (information on school work organization, information on students' attainments). The majority of the categories fit into the scheme of marketing communication (Kołodziejczyk 2012). What are the signs of this character of the communication? This sort of message creates an unambiguously positive image of the school, indicating that a big role in education is attributed to special events (ceremonies, celebrations), that the school is socially active in, although this activity manifests itself mainly in singular actions (social and charity actions), that trips and camps of various types are organized and that the premises are developed. A Polish primary school student is successful in diverse contests and competitions and has the opportunity to participate in interesting projects and to meet interesting people. The school obtains certificates, by which the school's attainments and high quality of its activity are highlighted. In the offer, an emphasis is put on extra-curricular classes, languages and extended curricula but the information about everyday work in class is missing. If the question of cooperation between the school and other subjects is mentioned, it is rather the exceptional and 
unconventional character of the cooperation that is underlined. Allowing parents to pursue their passions at school is an example of this original character of cooperation. The examples listed above can then be described as spectacular, unique and distinctive. School development, its successes, awards or participation in renown, national actions ("Góra grosza", "Szlachetna paczka") are presented. This is how the receiver is assured of the exceptional character of the school.

The overall image, reflected in the headmasters' statements, differs from the conception of public communication. In public communication, the information has to be provided in the most possible objective manner. The primary function of the messages mentioned by the headmasters is persuasive, which disqualifies them as neutral and objective. The receiver is not informed that the message released by the public organization serves the purposes of marketing and such a message does not meet the criteria of public communication.

School public communication practice shows that the strategic interests of these institutions are more important than the idea of objective and inclusive communication. The idea of building persuasive communication to influence the receivers is prevalent. The aim is rather to create a positive image of the school than to release an objective message. The emphasis is put on the school's attainments, the exceptional and spectacular character of its activity and not on the everyday work of the school and its problems. Little attention is paid to the attempts to include the stakeholders in active participation in communicating and solving the problems.

\section{References}

Borgonovi F, Mont G (2012) Parental Involvement in Selected PISA Countries and Economies. OECD Education Working Paper (73). OECD.

Davis B, Ellison L (1997) Strategic Marketing for Schools. London: Pitman Publishing.

Dobek-Ostrowska B (1999) Podstawy Komunikowania Spotecznego [Fundamentals of Social Communication]. Wroclaw: Wydawnictwo ASTRUM.

Dobek-Ostrowska B (2011) Komunikowanie Polityczne i Publiczne [Political and Public Communication]. Warsaw: Wydawnictwo Naukowe PWN.

Epstein J (2001) School, Family, and Community Partnerships. Preparing Educators and Improving Schools. Westview Press.

Fazlagić JM (2003) Marketingowe Zarządzanie Szkoła [Marketing Management School]. Warsaw: Centralny Ośrodek Doskonalenia Nauczycieli.

Habermas J (1999) Teoria Działania Komunikacyjnego, Racjonalność Działania a Racjonalność Spoleczna [The theory of Communicative Action, Rationality and Social Rationality] Warsaw: Wydawnictwa Naukowe PWN.

Habermas J (2004) Działanie komunikacyjne idetranscendentalizacja rozumu [Measuring communication and understanding]. Warsaw: Oficyna Wydawnicza.

Hall H (2007) Marketing w Szkolnictwie [Marketing in Education]. Poland: Wolters Kluwer.

Hill NE, Tyson DF (2009) Parental involvement in middle school: A meta-analytic assessment of the strategies that promote achievement. Developmental Psychology 45(3): 740-763. 
Kołodziejczyk J (2012) Jak szkoły Promuja Wartość Edukacji?[How do Schools Promote the Value of Education?]. Zeszyty Naukowe Instytutu Spraw Publicznych, Wydawnictwo Uniwersytetu Jagiellońskiego 3: 285-299. Krakow: Zarządzanie Publiczne.

Kowalczyk M (2009) E-urzad w Komunikacji z Obywatelem [E-office Communication with Citizens]. Warsaw: Wydawnictwa Akademickie i Profesjonalne.

Lockhart MJ (2005) How to Market your School. Universe Books.

Pardey D (1991) Marketing for Schools. London: Kogan Page.

Śpiewak P (2004) Komunitarianie. Wybór Tekstów [Communitarians. The Choice of Texts]. Warsaw: Fundacja Altheia.

Żardecka-Nowak M (2008) Demokracja Deliberatywna Jako Remedium na Ponowoczesny Kryzys Legitymizacji Wtadzy [Deliberative Democracy as a Remedy for Post-modern Crisis of Legitimacy]. Teka Komisji Politologii i Stosunków Międzynarodowych III: 29-40. Lublin.

Zémor P (1995) La Communication Publique [Public Communication]. Paris: PUF.

The Act (2001) Access to Public Information 112(1198).

The Regulation (2007) The Ministry of Internal Affairs and Administration regarding the Public Information Bulletin 10(68).

The Regulation (2013) The Ministry of National Education on Pedagogical Supervision amending the Regulation on Pedagogical Supervision 560. 
